\title{
EINSATZ DER MILCH-PROGESTERON-BESTIMMUNG IM RAHMEN VON EMBRYO-TRANSFER-PROGRAMMEN
}

\author{
F. ELSAESSER, B. SACHER, H. H. THIELSCHER, \\ J. UNSHELM und D. SMID'T
}

Institut $f$. Tievzucht und Tierverhalten, FAL, Mariensee, 3057 Neustadt I

Als Beitrag zur Problematik der Superovulation wurden Milchprogesteron (MP)-Profile von insgesamt I72 Kühen erstellt, bei denen durch Behandiung mit PMSG und darauf folgende Injektion von Prostaglandin eine Superovulation induziert worden war. Das Analysenintervall betrug bis zum I2. Tag nach der PMSG-Behandlung (Spülung) einen Tag, anschließend für weitere 5 Wochen 3 Tage. Obgleich eine endgültige statistische Bearbeitung noch aussteht (sowohl die Anzahl der Gelbkörper als auch die MP-Werte erwiesen sich als nicht normal verteilt), können bereits zwei wesentliche Feststellungen getroffen werden :

I) Hohe Progesteronwerte zum Zeitpunkt oder I-2 Tage nach der PMS-Behandlung lassen eine gute Reaktion erwarten (Korrelation zwischen MP-Wert und Anzahl Gelbkörper : 0.3 r-0.49).

2) Eine MP-Bestimmung 2-3 Tage vor der Spïlung kann als Entscheidungshilfe dafür dienen, ob eine Eigewinnung sinnvoll ist (Korrelation zwischen dem MP-Wert Io Tage post Stimulation und der Anzahl der Gelbkörper : 0.43-0.53).

Somit erscheint die Milchprogesteron-Bestimmung zur Beurteilung der endokrinen Voraussetzungen für die Superovulation und deren Erfolgschancen geeignet.

RELATIONSHIP BETWEEN COW FERTILITY AND MILK PROGESTERONE

\section{ZWIAUER and R. CIAUS (*)}

Lehrstuhl für Tierzucht der TU München, Freising-Weihestephan

(*) Institut f. Physiologie, Südd. Versuchs- und Forschungsanstalt für Milchwirtschaft, TU München, Fveising-Weihenstephan

For I20 cows the progesterone concentration in milk fat was determined three times a week from the first day post partum up to the third month of gestation. The influence of herd, season and lactation on some parameters of fertility as well as the relationship between milk yield or milk composition and these parameters have been investigated. Concerning the average duration of p.p. acyclia the differences between herds, seasons and lactations were significant. A high percentage of ovulations, indicated by progesterone curves, showed no symptomes of heat. The incidence of silent heat was unrelated to the fixed effects as well as to milk yield and milk composition, while the average daily concentration of progesterone in milk fat during a cycle showed significant differences between herd, seasons and lactations. Regressions on milk composition were low.

THE EFFECT OF PROGESTERONE TREATMENT ON THE FERTILITY OF DAIRY COWS

\section{B. DREW}

\author{
Agricultural Development and Advisory Service, \\ Ministry of Agriculture, Fishorics and Food, Winchester, England
}

A total of $3^{84}$ autumn calving Friesian cows were paired according to parity and milk yield and allocated at random to treated or control group. Cows in each group were allocated to one of six sub-groups according to date of previous calving. Milk samples were taken for progesterone assay from 16 of the 32 cows in each treated sub-group ten days before, and one day prior to treatment and twelve days after insemination. In the treated group ovulation was controlled by the administration of progesterone/cestradiol benzoate. Control cows were inseminated at the first observed oestrus after $25,30,35,40,45$ and 50 days for cows in sub-groups I to 6 respectively. Treated cows were inseminated on the roth and ith day after the start 